Journal of Social and Development Sciences

Vol. 2, No. 3, pp. 153-161, Sep 2011 (ISSN 2221-1152)

\title{
Analysis of Food Security Situation in Warri, Nigeria
}

\author{
Ben U. Omojimite \\ Delta State University, Abraka, Nigeria \\ buomojimite@yahoo.com
}

\begin{abstract}
This study attempts to investigate whether there could be food insecurity incidence in an "oil city" of Warri, Nigeria. The paper also examines the determinants of food insecurity among the households studied. The socio-economic characteristics of 260 households were collected by means of a structured questionnaire. A food insecurity index was constructed and was used to assess household food insecurity incidence. The results obtained were analysed by means of tables and percentages and found that on the average the incidence of food insecurity is high in the study area, implying that the benefits of oil and gas activities in Warri do not actually benefit all in the communities studied Also, a logit model was specified and tested to determine the factors that affect food insecurity in the study area. The results of the two approaches used in this study reveal that the age of household heads, sex of household heads, the type of occupation of household heads and dependency ratio all exacerbate food insecurity in the study area. The level of educational attainment of household heads, the nature of occupation of household heads and income of house heads tend to reduce the probability of households being food insecure. The study recommends food aid and food subsidy to the vulnerable in the area. It also recommends expanded educational facilities to enable inhabitants attain higher levels of education.
\end{abstract}

Key Words: Food security, Logit model, food security index, Warri, Nigeria

\section{Introduction}

Food in adequate quantity and quality is to humans as petrol and oil is to the combustion engine. Food is necessary to sustain life, stimulate growth and keep humans healthy. As food digestion takes place within the human body the nutrients from the food are derived, used or stored in the human body. Food nutrients provide the human body with power which could be converted to work. Work creates wealth and wealth determines the rate and character of development of a nation. There is therefore a positive link between availability and access to good food and the level and pace of development of a people. Food is necessary for healthy living and pleasurable living conditions. Good food in adequate supply provides all the nutrients needed for an active living. This in turn reduces ill-health, work stoppages and consumption expenditure on health at the household and national levels. It could be argued therefore that adequate supply of good food would reduce national budget on health care delivery thereby freeing more resources for the development of the other sectors of the economy.

Given these linkages between food security and development of nations, the global concern over food security is easily understood. In Nigeria the concern over food security has recorded several dimensions. First, there is the phenomenon of rising food import bills in the past three decades (Omojimite, 2010), necessitating the allocation of high levels of foreign exchange to food imports. Second, there is the concern over the problem of malnutrition. The World Health Organization proposed minimum daily intake of basic nutrients per capita. Meeting these minimum requirements, especially in the rural communities and the urban poor, remains a challenge till date. Third, over reliance on external sources to meet domestic food demand may actually diminish domestic efforts in local food production. Besides there may be real danger if the food exporters fail to supply or if the level of inflation rises in food exporting countries.

Several studies have investigated the food insecurity problem in Nigeria (Olayemi, 1996; Makinde, 2000, Adeyeye, 1992, Omonona \& Agoi, 2007). Most of the earlier studies focused on the quantitative measurement of food security by using consumption expenditures. Apart from Omonona \& Agoi (2007) attempts to study the food security phenomena on a case by case basis is sparse. This study aims at filling such gaps by focusing on the food security situation among households in an oil and gas producing environment in Nigeria. Warri 
harbours a large number of oil workers whose wages are usually higher than those in other professions. The consumption behaviour of workers whose wages are relatively higher may have demonstration effects on others living within the same environment. This in turn would have implications for the food security situation in such environments. The findings of this study would therefore be of benefit to food policy makers in designing differential food policies for such environments. The objective of this paper therefore is to empirically analyze the impact of the oil and gas production on the food security situation in Warri and environs in Delta State, Nigeria. The remainder of the paper is structured as follows. Following this introduction section 2 presents the conceptual framework and literature review. Section 3 describes the methodology adopted for the study. Section 4 analyses and discusses the results while section 5 concludes.

\section{Literature Review}

Although the concept "food security" is not a new phenomenon in many countries, it has commanded a global attention within the past three decades. According to the World Food Summit in 1996, "food security exists when all people, at all times, have physical and economic access to sufficient, safe and nutritious food for a healthy and active life". Gurkan (1995) defined food security as a "state of affairs where all people at all times have access to safe and nutritious food to maintain a healthy and active life". The description above clearly brings out three main components of food security namely food availability, food access and food utilization. At the national level, food is available if it is physically present from all sources including cultivation, processed, manufactured or imported. Food import is widespread in Nigeria, suggesting that domestic food production lags behind domestic demand for food. Food access refers to "the way in which different people obtains available food" according to the International Federation of Red Cross and Red Crescent Societies (2002). Some of the channels through which food is accessed includes but not limited to: home production, purchase, and barter and food aid. According to the International Federation (2002), food utilization refers to the way people use food such as the method of preparation, storage facilities and the health status of the individuals concerned.

Food availability is determined by several factors including climatic conditions which affect agricultural outputs. It is also affected by the availability of foreign exchange for food imports and food aids especially to developing countries. From the above, food availability depends on both internal and external factors. Very often the concept is used at the national or regional levels. Nevertheless, it could also be used in reference to household food security situations. Food access concerns the demand for food. Food demand is affected by economic as well as consumer preferences. Food must first of all be available before access to it. The key in food access is affordability. For the household the quantum of resources available determines the overall access. Food access could also be enhanced by physical and social infrastructures such as good network of roads and storage facilities. These facilities facilitate the distribution of food items from one region to another as well as permit the preservation of food for a longer period of time.

Food utilization varies from one community to another. It refers to the manner in which persons prepare their food and feeding practices. It is determined by the quantity, quality and a variety of dietary intake and general health conditions. According to Omonona \& Agoi (2007), the food security situation in a country is a measure of the strength or weakness of the agricultural sector. For example in Nigeria food insecurity problems have been attributed to several factors (Olayemi, 1996). These include inadequate budgetary provisions to the agricultural sector especially during the military regimes, bottlenecks in distribution, storage and marketing. It is also argued that the advent of petroleum oil as a major revenue earner shifted attention away from agriculture that led to declining productivity in the agricultural sector. Mwaniki (2003) observed that the root cause of food insecurity in developing countries is the inability of people to gain access to food due to poverty. Nigeria is ranked one of the poorest nations of the world. The poverty level is aggravated by high level official corruption, widespread unemployment and natural resource constraints. Also, Omonona \& Agoi (2007) noted that poverty limits economic access not only in monetary terms but also in terms of access to land, credit facilities, good health facilities all of which affect the food security status at the aggregate level. Idachaba (1989) noted that the growth rate of population is higher than the growth rate of food production thereby creating a shortage in food supply. This has led to rising prices of food items which have reduced access to adequate food especially in the rural areas. Also inflationary pressures in food 
exporting countries have sparked off domestic inflation that has made food increasingly inaccessible to the vulnerable groups.

\section{Methodology}

Area of Study: The area selected for this study is Warri metropolis and the adjourning towns all in Delta State of Nigeria. Warri is often regarded as "oil city" because, together with the adjourning towns of Ekpan, Ogunu, Effurun, Warri DSC/ Aladja, Okumagba layout, Enerhen and Agbara, harbours a large number of oil and gas workers. The combined population of the eight settlements is put at about 480,000 of which about 11,000 people are directly or indirectly employed in the oil and gas industry.

The Data: In generating, the data for this study 300 households were randomly selected from the eight communities listed below. The number selected from each community depended on the population of each of the communities. The streets in each community were clearly marked out and equal number of households was randomly selected from each street. A structured questionnaire was the instrument used to generate the data. A pilot study was successfully carried out using thirty copies of the instrument in the neighbourhood of the study area to enable us validate the instrument. The instrument was distributed to a total of 300 households in the eight communities (see table 1). 260 questionnaires were recovered. The questionnaires were administered by 8 assistants. The instrument (questionnaire) enabled us to collect information on household monthly income, monthly expenditure, occupation, age, and sex of household heads and household dependency ratio. Secondary data on food production and intake were obtained from the Nigerian Bureau of Statistics.

Table 1: Distribution of Questionnaires

\begin{tabular}{llll}
\hline Location & Distributed & Recovered & \% Recovered \\
\hline Ekpan & 45 & 38 & 84.44 \\
Ogunu & 40 & 36 & 90.00 \\
Effurun & 35 & 28 & 80.00 \\
Warri urban & 35 & 31 & 99.60 \\
Dsc/ Aladja & 30 & 27 & 90.00 \\
Okumagba L/Out & 40 & 36 & 90.00 \\
Enerhen & 40 & 33 & 82.50 \\
Agbasa Warri & 35 & 31 & 88.60 \\
Total & 300 & 260 & \\
\hline
\end{tabular}

Source: Compile from field survey 2010.

Method of Data Analysis: The responses on the questionnaires were sorted into the socio-economic groups as indicated earlier. Two approaches were used in carrying out this study. First, to enable us determine the food security situations in each socio-economic group in the study area, a food security index was constructed using the following formula.

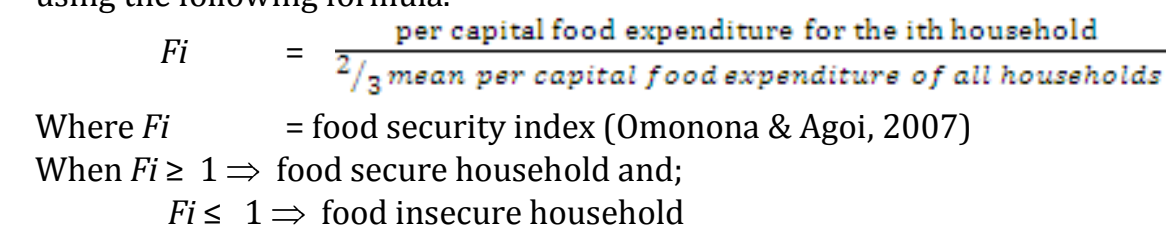

Applying this formula on the data generated from the questionnaire we are able to establish a food security line. The food insecurity incidence is then constructed for each socio-economic group. This permits a classification of each group either as food secure or food insecure. These information are presented in tables with percentages added. Second, an analysis of the determinants of household food security in the communities was undertaken to enable us see the relationship between socio-economic characteristics of households and their food insecurity situation. Gujarati (2003) noted that when the dependent variable is dichotomous, the use of the logit or probit model should be preferred to the linear regression model. Following other researchers (Hosmer and Lemeshew, 1989; Ojogho, 2010; Veen and Gebrehiwot, 2011), we 
specify a logit model that will enable us assess the effects of socio-economic characteristics on food security and the probability of a household being food insecure in the study area. Assuming the probability of a household being food insecure is determined by an underlying response variable that capture the true economic status of a household, the underlying response variable $\mathrm{R}$ in the case of binary status could be defined by the multivariate logit regression relation $R_{i}=\sum X_{i} \beta j+e_{i}$, where $\beta j=\beta_{1}, \beta_{2} \ldots \beta_{j}$ and $X_{i}=1, X_{i 2}, X_{i 3}, \ldots$ $\mathrm{X}_{\mathrm{ik}}$

The logistic expression are given as $\operatorname{prob}\left(R^{*}=1\right)=1-\mathrm{F}\left(\sum \mathrm{Xi} \beta \mathrm{j}\right)=\frac{e^{[\mathrm{Xi} \beta \mathrm{ji}}}{1+e^{\mathrm{Xii} i \mathrm{ij}}}$ and

$\operatorname{Prob}\left(R^{*}=0\right)=\mathrm{F}\left(-\sum \mathrm{X}_{\mathrm{i}} \beta \mathrm{j}\right)=\frac{e^{-\sum \mathrm{Ni} \beta \mathrm{ij}}}{1+e^{-\sum \mathrm{Xi} \beta \mathrm{j}}}=\frac{1}{1+e^{\sum \mathrm{Xi} \beta \mathrm{ij}}}$ where $\mathrm{F}$ is the cumulative distribution function for $\mu_{\mathrm{i}, \prime \prime}$ $\operatorname{prob}\left(R_{\mathrm{i}}=0 / \beta \mathrm{j} \mathrm{X}_{\mathrm{i}}\right)=\mathrm{F}\left(\left(-\sum \mathrm{X}_{\mathrm{i}} \mathrm{\beta j}\right)\right.$ and $\operatorname{prob}\left(R_{\mathrm{i}}=0 / \beta_{\mathrm{i}} \mathrm{X}_{\mathrm{i}}\right)=1=\mathrm{F}\left(-\sum \mathrm{X}^{1_{\mathrm{i}}} \beta \mathrm{j}\right)$. The likelihood function is given by

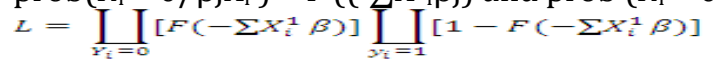

while the $\log$ likelihood function for the expression is $H(\beta)=\log L(\beta)=$ $\sum_{i=0}^{n} y_{i} \log \left[1-F\left(-\sum X_{i}^{1} \beta\right)+(1-y) \log F\left(-\sum X_{i}^{1} \beta\right)\right]$

Where $\mu_{\mathrm{i}}$, in F, follow a logistic cumulative distribution, $\mathrm{X}_{\mathrm{i}}$ are characteristics of households, and $\beta_{\mathrm{j}}$ are the coefficients for the respective variables in the logit function. The probability of a household being poor and the corresponding change in probability due to unit change in a variable $\mathrm{X}_{\mathrm{i}}$ are given as:

$\operatorname{prob}\left(R_{\mathrm{i}}=1 / \beta \mathrm{X}_{\mathrm{i}}\right)=\frac{e^{\varphi}}{1+e^{\varphi}}$ and $\frac{\mathrm{d}^{[}\left[\mathrm{prob}\left(R_{\mathrm{i}}=1 / \beta \mathrm{i} \mathrm{Xi}\right)\right]}{d X_{i}}=\beta_{i}(1-p) p$ where $\varphi$ is $\sum \beta_{\mathrm{i}} \mathrm{X}_{\mathrm{i}}$, is estimated value of the probability due to a variable, $\beta_{\mathrm{j}}$ is estimated regression coefficients (Ojogho 2010; Veen and Gebrehiwot 2011).

\section{Results}

Table 2: The Food Insecurity Line for the Households

\begin{tabular}{ll}
\hline Deciles & Mean per capita food expenditure (MPCFEM (N) \\
\hline First & $2,320.52$ \\
Second & $3,931.33$ \\
Third & 4789.32 \\
Fourth & 7232.54 \\
Fifth & $10,231.24$ \\
Sixth & $13,534.55$ \\
Seventh & $18,423.24$ \\
Eighth & $24,297.31$ \\
Ninth & $32,341.51$ \\
Tenth & $43,562.32$ \\
Total & $16,056.4$ \\
2/3 MPCFE & $10,704.27$ \\
\hline
\end{tabular}

*MPCFE: Mean per capita food expenditure.

Source: Authors calculations from field reports

From the table above, the food security line is calculated to be N10,704.27. Using the decision rule (Fi) established above, any household whose mean per capita food expenditure falls below N10,704.27 are classed, as food insecure while households whose mean per capita food expenditure is above N10,704.27 are food secure. From all the households studied the food insecurity, incidence is calculated to be 0.41 using the household income and expenditure information derived from the questionnaire used for this study. The demand for food especially in the study area may be influenced by several factors. These include the income of the household, the area located, sex of the head of the household, the size of the household as well as tastes and preferences of the household members. These considerations informed the inclusion of the variables in our questionnaire. In presenting the data, households are classified as food secure and food insecure depending on whether their mean per-capita food expenditure is above or below the food insecurity line as defined earlier. In the first segment of the analysis we employ tables and percentages in presenting and 
analyzing the results of our findings. In the second segment of the study, we present and analyze the results of the logit model. Table 3 below presents the data on the educational status of households.

Table 3: Distribution of Households Heads by Educational Status

\begin{tabular}{llllll}
\hline \multirow{2}{*}{ Educational status } & \multicolumn{2}{c}{ Food secure } & \multicolumn{2}{c}{ Food insecure } & Food insecurity \\
\cline { 2 - 5 } & Frequency & $\mathbf{\%}$ & Frequency & $\mathbf{\%}$ & incidence \\
\hline No formal Education & 7 & 3.85 & 8 & 10.25 & 0.62 \\
Primary & 25 & 13.73 & 9 & 11.4 & 0.34 \\
Secondary & 28 & 15.38 & 20 & 25.64 & 0.51 \\
Tertiary & 122 & 67.3 & 41 & 52.56 & 0.35 \\
Total & 182 & 100.00 & 78 & 100.00 & 0.41 \\
\hline
\end{tabular}

Source: Field survey 2010

Table 3 above presents the distribution of household heads by levels of educational status and the food insecurity incidence. From the table, food insecurity incidence is highest (0.62) for households whose heads are without formal education and least (0.35) for households whose heads have tertiary education. These findings tend to suggest that higher incomes that are associated with higher educational status reduce the incidence of food insecurity. In the table, households are profiled into food secure and food insecure. Household heads among the food secure group are made of $67.03 \%$ for those with tertiary education, $15 \%$ for those with secondary education, and $13.23 \%$ for those with no formal education. On the other hand in the food insecure group $51.56 \%$ of Household head had tertiary education. Household heads without formal education constitute $10.25 \%$, for primary and secondary education the corresponding figure is $11.54 \%$ and $25.64 \%$ respectively.

Table 4: Distribution of Households by size

\begin{tabular}{llllll}
\hline \multirow{2}{*}{ Household size } & \multicolumn{2}{c}{ Food Secure } & \multicolumn{2}{c}{ Food Insecure } & Food Insecurity \\
\cline { 2 - 5 } & Frequency & Percentage & Frequency & Percentage & Incidence \\
\hline $1-4$ & 113 & 62.0 & 26 & 33 & 0.45 \\
$5-7$ & 64 & 35.0 & 42 & 53.20 & 0.68 \\
$6-10$ & 5.4 & 3.0 & 7 & 9.80 & 1.00 \\
Above 10 & 0.00 & 0.0 & 3 & 4.00 & \\
Total & 182 & 100.00 & 78 & 100.00 & \\
\hline
\end{tabular}

Source: Field Survey 2010

Table 4 presents the distribution of household by size. Food insecurity incidence rises with the size of the households ranging from 0.45 to 1.00 for household groups 1-4 and 6-10 persons per household respectively. The food insecure group recorded 33\% for the 1-4 household members and 53.20\% for households with 5-7 members. Households with 6-10 members were $9.80 \%$ while households with members above 10, were $4 \%$.

Table 5: Distribution of Household heads by Occupation

\begin{tabular}{llllll}
\hline \multirow{1}{*}{ Occupation } & \multicolumn{2}{c}{ Food Secure } & \multicolumn{2}{c}{ Food Insecure } & Food Insecurity \\
\cline { 2 - 5 } & Frequency & Percentage & Frequency & Percentage & Incidence \\
\hline Oil workers & 115 & 63.20 & 33 & 42.30 & 0.35 \\
Traders & 33 & 18.13 & 22 & 28.20 & 0.36 \\
Civil servants & 29 & 15.93 & 18 & 23.10 & 0.42 \\
Unemployed & 5 & 2.74 & 5 & 6.40 & 0.31 \\
Total & 182 & 100.00 & 78 & 100.00 & 0.41 \\
\hline
\end{tabular}

Source: Field Survey 2010

In table 5, the occupations of household heads were classified as 'oil workers', 'traders', 'civil servants' and the 'unemployed'. The oil and gas group of workers accounted for $63.20 \%$ of the food secure group while traders and civil servants accounted for $18 \%$ and $15 \%$ respectively. For the food insecure group $42.30 \%$ were oil and gas workers while traders and civil servants accounted for $28.20 \%$ and $23.10 \%$. The food insecurity 
incidence is highest in the civil servant group (i.e. 0.42). Oil workers and traders recorded 0.35 and 0.36 respectively. This tends to reflect the fact that wages/salaries are lower in the civil service.

Table 6: Distribution of Households by Monthly Income

\begin{tabular}{llllll}
\hline \multirow{2}{*}{$\begin{array}{l}\text { Monthly household } \\
\text { income (N'000) }\end{array}$} & \multicolumn{2}{c}{ Food Secure } & \multicolumn{2}{c}{ Food Insecure } & Food Insecurity \\
\cline { 2 - 5 } Incidence
\end{tabular}

Source: Field Survey 2010

Table 6 presents the distribution of households by monthly income. From the table we observe that the incidence of food insecurity declines as income rises. The highest income group, i.e.. 100,000 naira and above recorded the least incidence of food insecurity. As income rises, food insecurity incidence rises, reach a peak and thereafter declines. Among the food secure group 25.27\% (which is the highest) falls within the highest income group N100,000:00 and above. The middle income group $(40,000-60,000)$ was $11.53 \%$ which represents the least in that income classification. For the food insecure group the percentage points declines as income rises. This implies that the number of food insecure household's declines as income rises.

Table 7: Distribution by Age of Households Heads

\begin{tabular}{lllllll}
\hline \multirow{2}{*}{$\begin{array}{c}\text { Age of Household } \\
\text { Head }\end{array}$} & \multicolumn{2}{c}{ Food Secure } & \multicolumn{2}{c}{ Food Insecure } & Food Insecurity \\
\cline { 2 - 5 } Incidence
\end{tabular}

Source: Field Survey 2010

Table 7 above summaries the age distribution of household heads and the food insecurity incidence. The table reveals that food insecurity incidence increases with the age of household heads. Between the ages $21-70$ years the incidence increased from 0.30 to 0.52 . The age group $21-70$ year has some distinctive features. At the lower segment of that age bracket, wages are relatively low as they constitute the lower cadre of the labor force. Family sizes are also small within the age group 21 to 30 years. These help to explain the level of food insecurity incidence observed in the table 7 . Within the age bracket 41 to 50 years household head's incomes would have raised and at the same time responsibility for a larger family size would increase food insecurity incidence as recorded on the table. Between 60 and 70 years most household heads would have gone on retirement with the attendant lower incomes and an increase in food insecurity incidence. Among the food secure group 30\% of the households fall within the age group 31-40 years. Thereafter the percentage declines as the age of household heads increases. This picture is also replicated in the food insecure age groups of household heads. Percentage of household heads in the food insecure group declined from $30 \%$ for the (3140 ) age group to $3.55 \%$ for the age group 70 years and above.

Table 8: Distribution of Household Heads by Sex

\begin{tabular}{llllll}
\hline Sex & \multicolumn{2}{c}{ Food Secure } & \multicolumn{2}{c}{ Food Insecure } & Food Insecurity \\
& Frequency & Percentage & Frequency & Percentage & Incidence \\
\hline Male & 151 & 82.97 & 61 & 78.21 & 0.37 \\
Female & 31 & 17.03 & 17 & 21.79 & 0.46 \\
Total & 182 & 100.00 & 78 & 100.00 & \\
\hline
\end{tabular}

Source: Field Survey 2010 
Tables 8 present the distribution of household's heads by sex and food insecurity incidence. Clearly the table reveals that food insecurity incidence is highest where household's heads are female (0.46). Among the food secure households $82.97 \%$ of the household heads are males while only $17 \%$ are females. On the other hand among the food insecure households $78.2 \%$ of the household heads are males while $21.79 \%$ are females.

Table 9: Distribution of Household by dependency Ratio

\begin{tabular}{|c|c|c|c|c|c|}
\hline \multirow{2}{*}{$\begin{array}{l}\text { Dependency } \\
\text { ratio }\end{array}$} & \multicolumn{2}{|c|}{ Food secure } & \multicolumn{2}{|c|}{ Food Insecure } & \multirow{2}{*}{$\begin{array}{c}\text { Food Insecurity } \\
\text { Incidence }\end{array}$} \\
\hline & Frequency & Percentage & Frequency & Percentage & \\
\hline No dependency & 63 & 34.62 & 18 & 23.08 & 0.30 \\
\hline Less than 1 & 54 & 29.67 & 12 & 15.39 & 0.32 \\
\hline Equal to 1 & 27 & 14.84 & 7 & 8.97 & 0.39 \\
\hline Greater than 1 & 38 & 20.87 & 41 & 52.56 & 0.48 \\
\hline Total & 182 & 100.00 & 78 & 100.00 & 0.41 \\
\hline
\end{tabular}

Source: Field Survey 2010

From table 9, food insecurity incidence increases from 0.30 (for no dependency) to 0.48 (for greater than 1 dependency ratio). Here dependency ratios are defined as the proportion of household members that are not working to those that are working. From table 9, 34.62\% of households have no dependants.

Interpretation of the Result of the Logit Model:

Table 10: Definition of Variables used in the estimated logit Equation

\begin{tabular}{|c|c|c|}
\hline Variable & Definitions & Symbols \\
\hline Food insecurity (dependent) & $\begin{array}{l}\mathrm{P}=1 \text { if food insecure } \\
\quad=0 \text { otherwise (food insecurity } \\
\text { estimates) }\end{array}$ & $\mathrm{P}$ \\
\hline \multicolumn{3}{|l|}{ Explanatory variables } \\
\hline Sex of household head & $\begin{aligned} \text { Sex } & =1 \text { if male } \\
& =0 \text { otherwise }\end{aligned}$ & SHH \\
\hline \multirow[t]{2}{*}{ Education level of household head } & $\begin{array}{l}=1 \text { if primary } \\
=0 \text { otherwise }\end{array}$ & ЕНHP \\
\hline & $\begin{array}{l}=1 \text { if secondary } \\
=0 \text { otherwise } \\
=1 \text { if tertiary } \\
=0 \text { otherwise }\end{array}$ & $\begin{array}{l}\text { EHHS } \\
\text { EHHT }\end{array}$ \\
\hline Age of household head (years) & & $\mathrm{AHH}$ \\
\hline $\begin{array}{l}\text { Per capital income of household } \\
\text { head }(\mathrm{N})\end{array}$ & & $\mathrm{PCIH}$ \\
\hline Household size & & HHS \\
\hline \multirow{4}{*}{$\begin{array}{l}\text { Household dependency ratio } \\
\text { Occupation of household head }\end{array}$} & & HDR \\
\hline & $\begin{array}{l}=1 \text { if oil and gas worker } \\
=0 \text { otherwise }\end{array}$ & OHOG \\
\hline & $\begin{array}{l}=1 \text { if trader } \\
=0 \text { if otherwise }\end{array}$ & OHT \\
\hline & $\begin{array}{l}=\text { civil servant } \\
=0 \text { otherwise }\end{array}$ & OHCS \\
\hline
\end{tabular}


Table 11: Binomial Logit Estimate for the Determinants of Food Insecurity and the Probabilities of a Household being Food Insecure

\begin{tabular}{lllll}
\hline Variable & \multicolumn{1}{c}{$\begin{array}{c}\text { Estimated } \boldsymbol{\beta} \\
\text { values }\end{array}$} & \multicolumn{1}{c}{$\begin{array}{c}\text { Coefficients Z- } \\
\text { values }\end{array}$} & \multicolumn{1}{c}{ Prob (Y=1) } & $\begin{array}{c}\text { Marginal effect } \\
(\mathbf{d p} / \mathbf{d x})\end{array}$ \\
\hline SHH & -0.129 & -0.098 & 0.476 & $-0.032^{*}$ \\
EHH & & & & $-0078^{*}$ \\
Primary* & $-0.312^{* * *}$ & $-0.147^{* *}$ & 0.461 & $-0.222^{*}$ \\
Secondary* & $-1.503^{* * *}$ & $-0.797^{* * *}$ & 0.321 & $-0.286^{*}$ \\
Tertiary* & $-2.562^{* * *}$ & $-1.922^{* *}$ & 0.128 & 0.036 \\
HHS & $0.321^{* * *}$ & 1.723 & 0.867 & -0.209 \\
OHG & & & & -0.106 \\
OHOG* & $-1.203^{* *}$ & $-1.277^{*}$ & 0.221 & 0.041 \\
OHT* & $-0.431^{* *}$ & $-1.531^{*}$ & 0.211 & $0.005^{* *}$ \\
OHCS* & 0.304 & 1.662 & 0.721 & 0.005 \\
HDR & $0.035^{* *}$ & 1.481 & 0.815 & -0.00006 \\
AHH & 0.031 & 1.452 & 0.812 & \\
PCIHH & -0.000417 & -1.660 & 0.160 & \\
Constant & -2.763 & & & \\
\hline
\end{tabular}

Count $\mathrm{R}^{2}=0.84, \mathrm{R}^{2} \mathrm{MCF}=0.41$

$* \frac{d y}{d x}$ is for discrete change of dummy variable, ${ }^{* *}$ Significant at $5 \%$ level, ${ }^{* * *}$ significant at $1 \%$ level (see table 10 for meanings of abbreviation)

Table 11 reveals that household head who are civil servants (OHCS), household dependency ratios (HDR), household size (HHS) and age of household head (AHH) are positively related to the probability of a household being food insecure. On the other hand, household heads who are oil and gas (OHG) workers, the level of education of households heads (EHH), Age of household heads (AHH), income of household heads (PCIH) all have negative relationship with the probability of a household being food insecure. Table 11 shows that occupation (i.e. oil and gas workers), education (i.e. primary, secondary and tertiary) are determinants of food insecurity as all these variables are significant. The respective probabilities of primary EHHP (0.461), secondary EHHS (0.321), tertiary EHHT (0.128), oil and gas OHOG(0.221) and Trader (OHT 0.211) all have low probabilities of a household being food insecure. Thus the more education one acquires, the higher the probability of reducing food insecurity incidence. The income of household heads is also found to be a significant determinant of food insecurity. The logit value of the household size was 1.723, with a partial coefficient of 0.321 . This implies that as the size of household rises by a unit on the average, the estimated logit increases by 0.321 and adds 0.036 to the probability of a household being food insecure for every unit change in household size.

\section{Findings and Conclusion}

The study reveals that food insecurity is lower for those engaged in the oil and gas sector. This category of persons earns relatively higher wages than the other groups studied. Food insecurity incidence is highest for civil servant (including teachers, 0.42) and lowest for the unemployed (0.31).Food insecurity incidence decreases with the level of education. It is highest for those without formal education (0.62) and lowest for those with tertiary education. The study also revealed that food insecurity incidence decreases as the level of income increases. It decreased from 0.61 to 0.21 for the income group 21,000 - 40,000 and 81,000 - 100,000 respectively. The study also revealed that food insecurity incidence is higher in households where the heads are female. These findings were also supported by the results of the logit model that we estimated.

The food insecurity incidence has a direct relationship with the size of the household. The study revealed that small sized households recorded an incidence of 0.27 while large size households had food insecurity incidence of 1 . The study also found that food security incidence increases with the age of the head of the household. Again the results of the logit model supports this finding the food insecurity incidence for the entire households surveyed was 0.41 . This shows that in general, although the oil- sector drives the economy of the study area, the food insecurity incidence in the area is high. This indicates that the oil and gas wealth of 
Warri (oil city) has not been equitably distributed and that the high wages in the oil and gas sector distorts the consumption behavior in the study area. The study also found that food insecurity incidence increases with the level of dependency ratio. It rose from 0.30 to 0.48 for dependency ratio of zero dependency ratio and ratio of greater than 1 . The result from the logit model also supports this.

From the findings of this study the following recommendations are made. First, since the oil sector wages are relatively higher in the areas studied with its attendant inflationary effects, a programmed of food subsidy or food aid should be put in place for the benefit of low income earners and other vulnerable groups in the area and be funded by government. Second, for the public servants in the area, government should provide special allowances to augment their earnings. Third, since food insecurity incidence was found to increase in female headed households, appropriate legislations should be made at the local council level to discourage broken marriages. In conclusion, although this study has its own limitations in terms of the number of households covered, attempts should be made to carry out case by case studies across different geo-political areas. The present study has revealed that socio-economic factors such as the level of educational status, monthly income, size of the households, and occupation of household heads all affect food insecurity situation.

\section{References}

Adeyeye, V. A. (1992). An assessment of food security in Nigeria. Final report of a study commissioned by FAO, Rome.

Gujarati, D. (2003). Basic econometrics. Fourth edition. McGraw-Hill Companies, New York, USA.

Gurkan, A. A. (1995). Determining the Structure of Food Insecurity at the Global Level: A Cross Country Framework for Analyzing Policy Issues for the Agro-Food Sector. Économies et Sociétés: La sécurité alimentaire à court et à long terme. 29(3-4), 51-65.

Hosmer, D. \& Lemeshew, S. (1989). Applied logistic regression. Wiley InterScience, New York USA.

Idachaba, F. S. (1989). The nature of Nigerian food problem, paper presented at the National symposium on Nigerian food question organized by college of Agricultural economics and extension, University of Agricultural economics and extension, University of Agriculture Makudi, Nigeria. (1989).

IFPRI (International Food Policy Research Institute). (2002). Reaching Sustainable food security for all by 2020. Getting the priorities and responsibilities right. Washington, DC. IFPRI.

International Federation of Red Cross and Red Crescent societies (2002). Long-term food security: investing in people and livelihoods. www.ifrc.org.Accessed Nov 152010.

Makinde, K. O. (2000). Measurements and determination of food security in Northern Guinea Savannah of Nigeria. Unpublished PhD Thesis, Department of Agricultural Economics, University of Ibadan.

Mwaniki, A. (2003). The Utilization of locally Grown Plant Materials in the production of an intervention formulation for Malnourished Children in Marginal Areas. The Case of Makindu location Makueni District. Masters. Thesis, University of Nairobi.

Nigeria's Agriculture and food security challenges. www.fao.org/tca/work05/Nigeriapdf. Accessed Nov 15, 2010.

Ojogho, O. (2010). Determinants of food insecurity among arable farmers in Edo State, Nigeria. Agricultural Journal. 5(3), 151-156.

Okunmadewa, F. (2001). Poverty Reduction in Nigeria: A Four-point Agenda. Annual Guest Lecture, University of Ibadan, Ibadan.

Olayemi, J. K. (1996). Food Security in Nigeria, Development policy center policy report 2, Ibadan.

Omojimite, B. U. (2010). Food Security in Nigeria: Issues, challenges and Prospects, in A.S. Akpotor and G. Imo (eds): Homeland security and peace building in Nigeria. Faculty of the social sciences, Delta State University, Abraka.

Omonona, B.T. \& Agoi, G. A. (2007). An Analysis of Food Security Situation among Nigerian Urban Households: Evidence from Lagos State, Nigeria. Journal of Central European Agriculture, 8(3), 397-406.

Veen, v. A. \& Gebrehiwot, T. (2011). Effect of Policy Interventions on food security in Tigray, Northern Ethiopia. http://www.ecologyandsociety.org/vol16/iss1/art18/ . Accessed April 22, 2011

World Bank (1991). Nigeria: strategy for food and nutrition security. World bank document report no 9040.

World Bank (1986). Poverty and Hunger; Issues and options for food security in developing countries. A world Bank policy study. Washington.

World Food Summit (1996). Rome Declaration on World Food Security. 